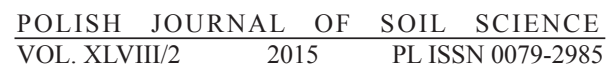

DOI: $10.17951 / \mathrm{pjss} / 2015.48 .2 .197$

Soil Chemistry

\author{
MARCIN ŚWITONIAK, MICHAŁ DĄBROWSKI, \\ AGNIESZKA ŁYSZKIEWICZ*
}

\title{
THE INFLUENCE OF HUMAN-INDUCED EROSION ON THE SOIL ORGANIC CARBON STOCK IN VINEYARDS OF FORDON VALLEY
}

Abstract. The aim of this paper has been to define the influence of accelerated erosion on basic properties and the SOM stocks of soils within vineyards located on western slopes of the Lower Vistula Valley. The study was conducted within four vineyards situated $30 \mathrm{~km}$ north-east from Bydgoszcz. During the field work 44 auger holes were made. On the basis of results of drilling, eight places for soil pits were selected. The study sites were characterised by considerable diversity of soil cover. The SOM stocks in studied profiles ranged from 2,98 to $63,9 \mathrm{~kg} \mathrm{~m}^{-2}$. The upper parts of the Lower Vistula Valley slopes were dominated by Luvisols developed from glacial tills. Pedons located in toe and foot slope positions represented Chernozems and Phaeozems developed from layered fluvial sediments. The translocation of soil was caused by accelerated erosion that heightened differentiation in the primeval SOM stocks. Although, the Luvisols were truncated in result of accelerated erosion, they were not significantly depleted in organic matter stocks. Most Chernozems and Phaeozems located in toe and foot slope positions were enhanced in SOM stocks due to accumulation of humus colluvial material on their surface. The short period of existence of vineyards makes it impossible to determine the impact of grass roots decay on carbon content in surface soil horizons between rows of vine.

The contents and stocks of soil organic matter (SOM) strongly depend on many factors, including temperature, moisture, texture, and topography [41;59]. Land use conversion, especially transformation of forest into arable fields, may lead to reduction of the SOM stocks [19]. Physical disturbance with tillage dis-

*M. Świtoniak, DSc.; M. Dąbrowski, DSc., A. Łyszkiewicz, DSc.; Department of Soil Science and Landscape Management, Nicolaus Copernicus University, Lwowska 1, 87-100 Torun, Poland. 
rupts macro-aggregates and exposes previously protected soil to microbial processes which increase the rate of the SOM decomposition $[6,60]$. The reductions in the SOM as a result of cultivation, intensified oxidation and increasing biological activity was also described in many previous papers $[4,5,50]$. Moreover, the intensification of tillage led to severe erosion and the loss and redistribution of soil organic carbon (SOC) [14]. Depletion of the SOM due to soil truncation was also confirmed in the vineyards of Catalonia, North-Eastern Spain [32]. According to the research conducted in the Lublin Upland [23], accelerated erosion led to the significant decrease from the average of $2.3 \%$ to about $1 \%$ of the SOC in surface horizons during the first few decades after deforestation of Luvisols.

Erosion processes have significantly affected the structure of soil cover and soil profile morphology of northern Poland [43, 49, 51, 52, 53, 54]. The strongest erosional disturbances occur in regard to arable soils developed on ground moraine deposits in hummocky moraine plateau landscapes $[56,58]$. Surface soil horizon truncation occurs on upper parts of slopes. The effect of the translocation of soil material is also a common occurrence of colluvial soils in lower part of slopes and depressions. The maximum thickness of colluvium recorded in the Brodnica Lake District was about $3 \mathrm{~m}[56,57]$. This material often contains significant amounts of the SOC [33, 34].

The optimal SOM content in surface horizon for the vine plantation is within the range of 20-30 [ $\left.\mathrm{g} \mathrm{kg}^{-1}\right]$. Too small amounts of it affect the markedly worse physical properties of the soil. On the other hand high contents may cause excessive growth of shrubs and wooden branches of vine $[18,63]$. The vineyards of the Fordon Valley are located on steep and long slopes. Erosional redistribution of humus material could lead to substantial changes in the SOM stocks. The aim of this paper has been to define the influence of erosion on basic properties and the SOM stocks of soils within vineyards located on western slopes of the Lower Vistula Valley.

\section{MATERIALS AND METHODS}

The study was conducted within four small and young vineyards (Fig. 1) on the total area not exceeding 1 ha. Before the Twenty-first Century (Talerzyk - 2010, Kozielec I - 2011, Kozielec II - 2013 and Kozielec III - 2007) the investigated areas had been used for other agricultural purposes. The vineyards are situated $30 \mathrm{~km}$ north-east from Bydgoszcz, on western slopes of the Lower Vistula Valley which separate the Świecie Plateau from the Fordon Valley (Fig. 1). The Świecie Plateau is a flat and undulating morainic plain. The general outline of its relief was formed during the Pomeranian Phase of the Vistulian Glaciation, ca. 16-17 ka CE [31]. The plateau surface lies at the altitude of about 95-100 $\mathrm{m}$ a.s.1. The Fordon Valley is the southern section of the Lower Vistula Valley. The beginning of the development of the valley is associated with the 


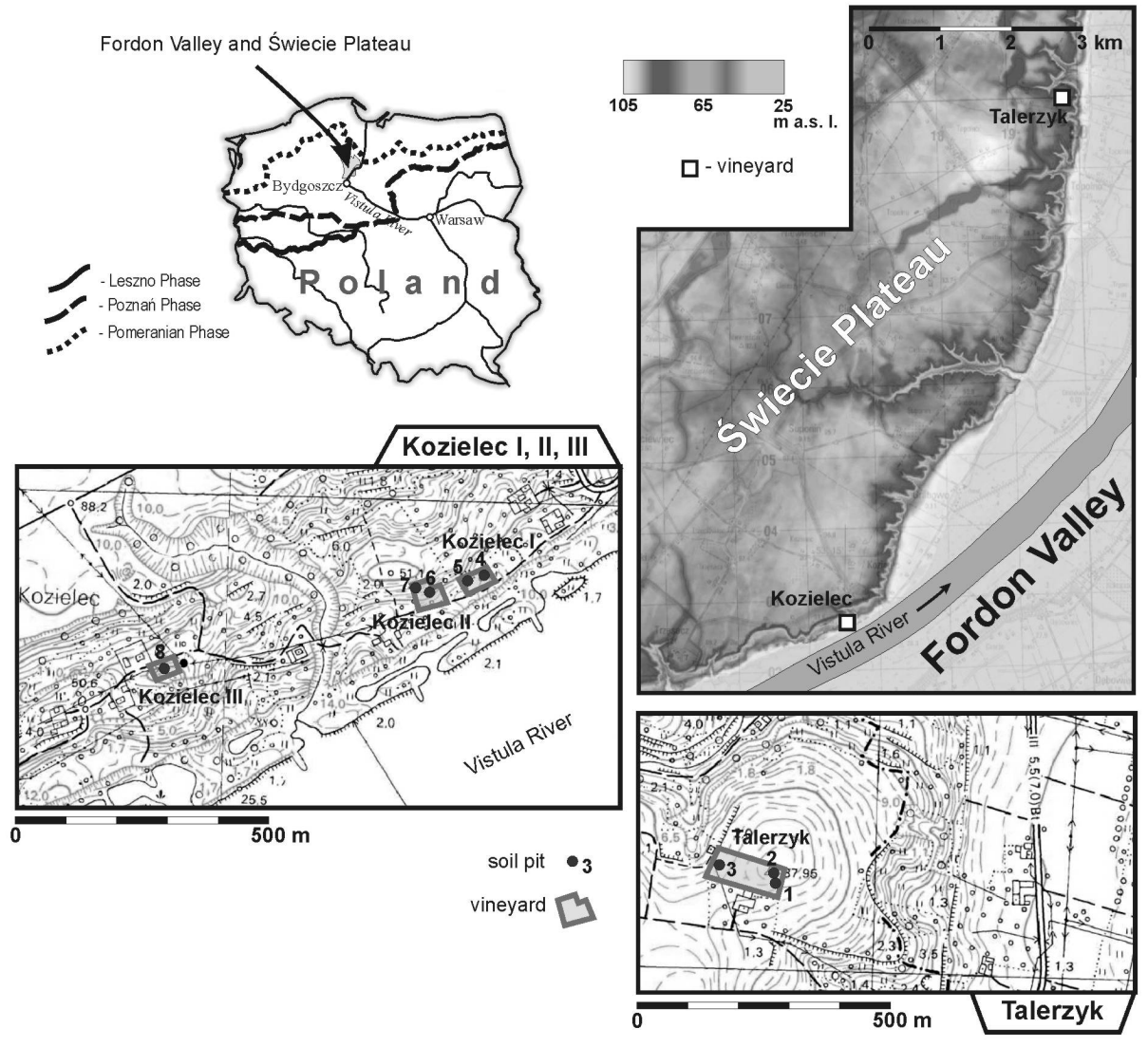

Fig. 1. Location of the study sites.

change in the flow of the Vistula River approximately 14 thousand years ago, during the Oldest Dryas $[16,17,61,62]$. Before this period the Vistula River had flown westwards through the Noteć-Warta ice-marginal valley. The relief of the valley was shaped in the course of the whole Holocene. The bottom of the valley is a contemporary floodplain of the Vistula River and in the vicinity of study sites it has the altitude of about $25 \mathrm{~m}$ a.s.l.

The first vineyard is located near Topolno village, in the upper part of the Vistula Valley slopes at the altitude of 85-88 $\mathrm{m}$ a.s.l. Its surface lies on a small "morainic headland" surrounded by small erosion valleys in the west-north, north and south (Fig. 1). The eastern border of the headland is made up of the long and steep slopes of the Vistula Valley. The other three vineyards are located in Kozielec village. The vineyard Kozielec I lies in a small depression on the toe slope position of 35-37 $\mathrm{m}$ a.s.1. Kozielec II extends on the lower slope between 35-42 $\mathrm{m}$ a.s.l. The last vineyard (Kozielec III) occupies a small hill forming a convex form within the middle part of the Vistula Valley slope at altitudes 
of approximately $60 \mathrm{~m}$ a.s.l. The soil cover of four vineyards was described in detail. During the field work 44 auger holes were made. On the basis of results of drilling, eight places for soil pits were selected.

The samples for laboratory analysis were taken from all the genetic horizons and the following soil analysis was performed [2, 64]: bulk density (BD) by means of the oven-dry method, organic carbon content (Soil Organic Carbon, SOC) - by means of oxidation in the mixture of $\mathrm{K}_{2} \mathrm{Cr}_{2} \mathrm{O}_{7}$ and $\mathrm{H}_{2} \mathrm{SO}_{4}$, total nitrogen content - Kjeldahl method, $\mathrm{CaCO}_{3}$ content - Scheibler volumetric method, particle-size distribution - by means of the sieve method and the hydrometer (Bouyoucos aerometric) method; $\mathrm{pH}$ of the soil-to-solution ratio of 1:2.5 using $1 \mathrm{M} \mathrm{KCl}$ and $\mathrm{H}_{2} \mathrm{O}$ as the suspension medium; Colour has been described according to Munsell [36]. The SOC stocks were calculated for each soil horizon by multiplying the concentration of the SOC $\left[\mathrm{g} \mathrm{kg}^{-1}\right]$ by BD $\left[\mathrm{g} \mathrm{cm}^{-3}\right]$ and layer thickness $[\mathrm{cm}]$. To get the units expressed in terms of $\mathrm{kg} \mathrm{m}^{-2}$, the resulting figures of multiplying were divided by 100 . The total SOC stocks for each soil profile are sums of the stocks in respective horizons. The soil organic matter stocks (SOM stocks) were calculated by multiplying the SOC stocks by 2 . The soils were classified according to WRB [20]. Descriptions of horizons are given after the Guidelines for Soil Description [15].

\section{RESULTS AND DISCUSSION}

\section{Properties, genesis and systematic position of investigated soils}

The investigated vineyards were characterised by considerable diversity of soil cover. Within Topolno site pedons were developed from glacial tills (Profiles $1,2,3)$. In these soil horizons argic $(\mathrm{Bt})$ with distinct clay illuviation was observed. Abundant illuvial clay coatings and infillings were easily visible already at the stage of the field work. Absolute content of clay in Bt horizons was not significantly higher than the amount of this fraction in parent materials (C and Ck horizons) but the presence of clay films on the surface of soil aggregates confirmed their illuvial character. Because of high base status in the illuvial horizons (high $\mathrm{pH}$ values) and high activity of the clay fraction they were classified as Luvisols [20]. Widespread occurrence of Luvisols developed from glacial deposits was also described in other young morainic regions of Poland $[9,10,24$, $29,43,56,57,58]$. This type of soils has also been marked on detailed (1: 5000$)$ soil-agricultural maps of the described area. Soils of Topolno site differ significantly with regard to solum thickness and genetic horizon development. Only one pedon (Profile 2) had a marked textural differentiation with clearly visible eluvial E horizon (Fig. 2, Table 1). The upper boundary of illuvial horizon was found at the depth of $40 \mathrm{~cm}$. The presence of eluvial horizon between $\mathrm{A}(\mathrm{p})$ and Bt horizon (Fig. 2) and abrupt textural difference was expressed by Albic and 


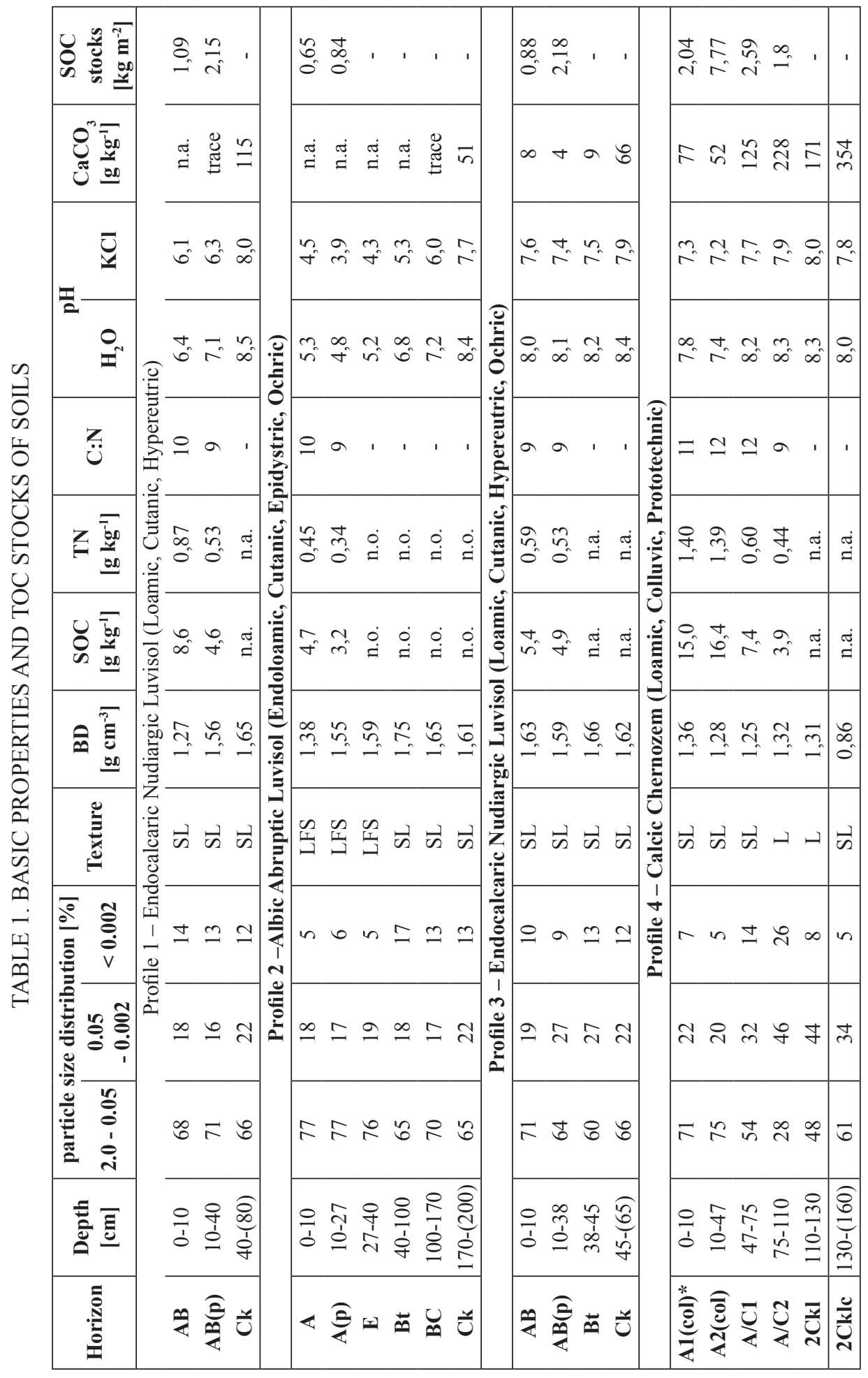




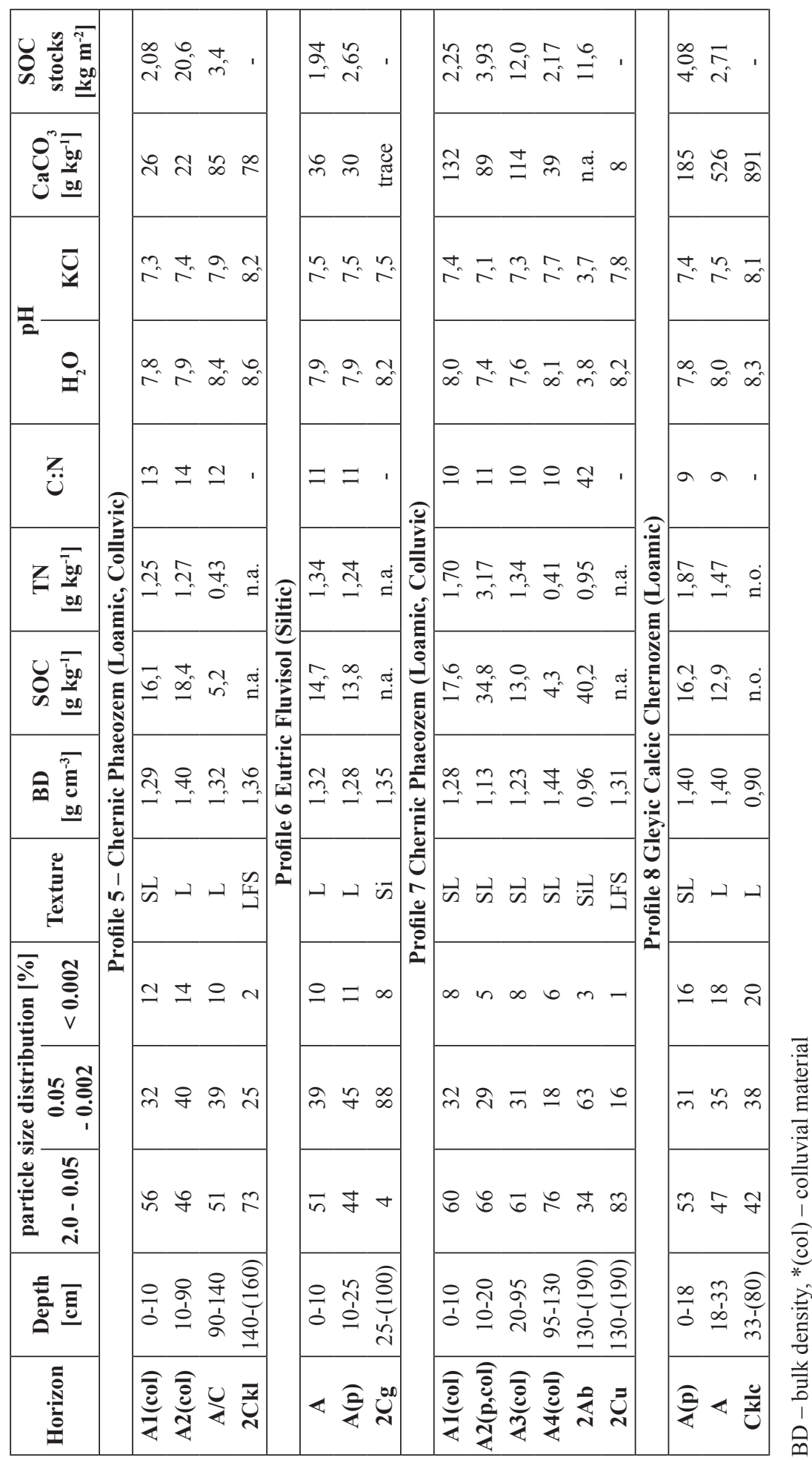



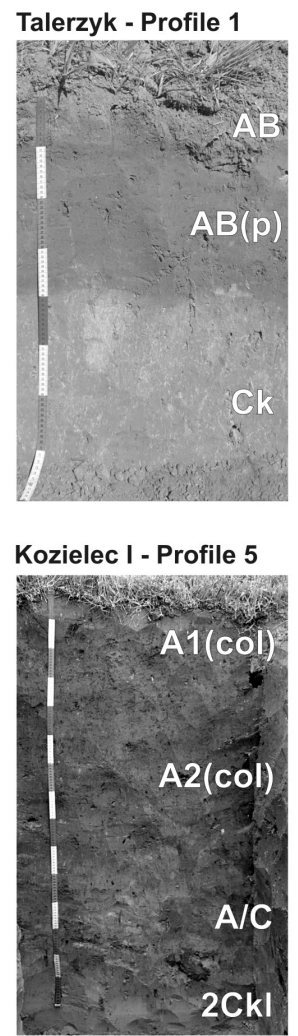
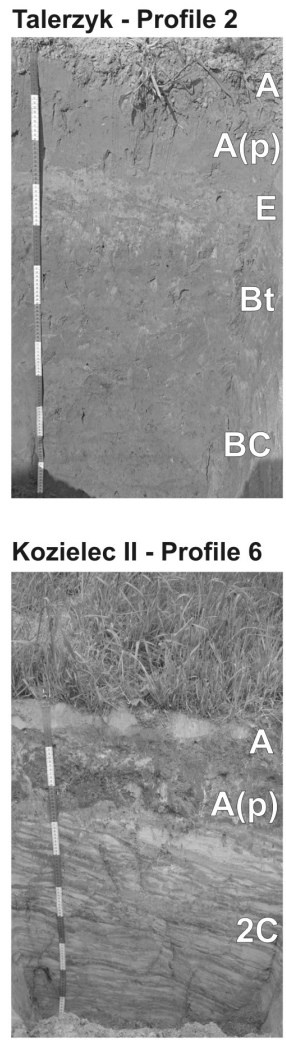
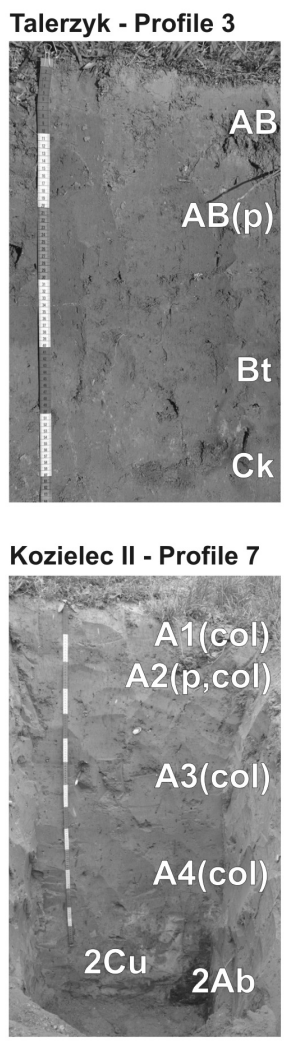
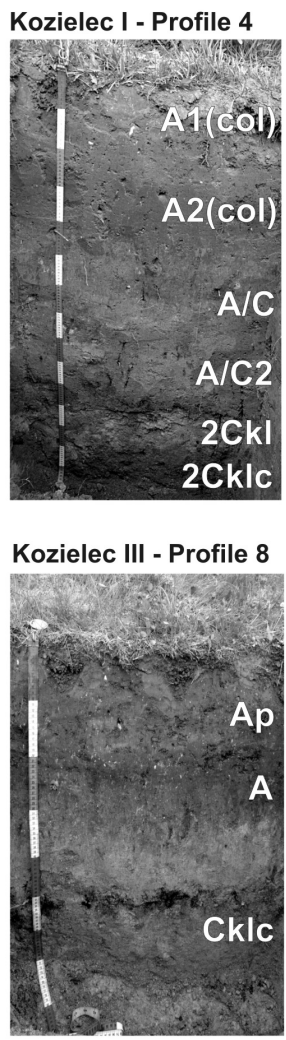

Fig. 2. Soil morphology.

Abruptic principal qualifiers. In Profiles 1 and 3 the Bt horizons started at the mineral soil surface which was indicated in their systematic position by using Nudiargic qualifier. In both cases illuvial horizons were strongly disturbed by former ploughing (Fig. 2). In Profile 1 the whole Bt horizon was incorporated into plough layer while in the Profile 3 only the lowest part of illuvial zone $(8 \mathrm{~cm})$ was not transformed by ploughing. Previous investigations demonstrated that the lack of eluvial horizons between $\mathrm{Ap}$ and $\mathrm{Bt}$ and exposition of $\mathrm{Bt}$ horizons on soil surfaces is the result of soil truncation $[3,12,21,24,42,43,49,58]$. The erosional alteration of Luvisols which led to the formation of A-B-C pedons was also identified in the erosion-vulnerable loess areas of Poland [11, 23, 39, $40,46]$. The primary variability in the thickness of the soil horizons makes the exact calculation of soil losses based on the profile truncation not possible [8, 37]. It is only possible to determine the several classes of soil transformation by accelerated erosion [22, 43, 49]. According to previous studies [56, 57] Profiles 1 and 3 represent strong stage of truncation with the approximate soil loss of about $0.6 \mathrm{~m}$. Profile 2 was classified as slightly eroded soil. In comparison with fully developed forest Luvisols [56] it is characterised by smaller (about $0.2 \mathrm{~m}$ ) thick- 
ness of eluvial zone. The topographic location of the Topolno Vineyard favours the alterations caused by erosion in studied pedons (1-3 profiles). The whole area was situated in the upper and convex part of slopes which are exposed to soil erosion. The different degree of erosion in particular soils suggests that the initial micro-relief was more varied than the contemporary surface.

Soils of Kozielec I Vineyard - Profiles 4 and 5, and Profile 7 situated on Kozielec II site had pronounced accumulation of organic matter from the mineral surface to the great depth of solum (110, 140 and $190 \mathrm{~cm}$, respectively). In these pedons humus horizons met the criteria of chernic horizons (Table 1) - it had dark colour, significant content of organic carbon, high base saturation and biological activity [20]. Profile 4 was classified as Chernozem. It had calcic horizon with more than $15 \%$ of primarily and secondary carbonates started at the depth of $110 \mathrm{~cm}$. The considerable amount of carbonates was also found in other horizons of the mentioned profiles (4,5 and 7). These horizons could not be treated as calcic due to the lack of secondary forms (in humus horizons) or insufficient (below 15\%) contents of calcium carbonates (Table 1). The origin of the carbonates still remains unrecognised. Their commonness in the studied soils may be associated with lateral subsurface flow from morainic plateau [55]. Numerous calcareous sinters in the bottom of the Lower Vistula Valley developed as the result of subsurface flow of carbonates from surrounded plateaus and were described by Bartkowiak and Długosz [1] or Kordowski [25]. The high amount of carbonates in humus materials may also be the effect of erosional redeposition of calcareous materials. According to WRB [20], Profile 5 and 7 were put into Phaeozem Reference Soil Group (RSG). Irrespectively of RSG, significant thickness of humus horizons indicates the colluvial nature of described soils $[7,56]$. This is also confirmed by occurrence of the buried A horizon in Profile 7 at the depth of $130 \mathrm{~cm}$. The presence of such a well-preserved buried horizon $(2 \mathrm{Ab})$ is an evidence of allochthonous origin of relatively young surface deposits. Thick humus horizons contained colluvium, which has already been described by many authors in northern Poland, e.g. [33, 38, 45]. The alluvial genesis of humic deposits should be excluded. The investigated area lies above the contemporary floodplain. Moreover, topographic settings and land use in the past were strongly conducive to colluvial deposits accumulation. Profiles 4, 5 and 7 occupied the lower slope and toe slope positions while the terrain above Kozielec 1 and 2 Vineyards was ploughed at least until the 50s of the Twentieth Century. In Profiles 4 and 5 the effects of mixing by ploughing were visible at the depths of 110 and $140 \mathrm{~cm}$. In pedon 7, some parts of $2 \mathrm{Ab}$ horizon were completely destroyed and replaced by non-humus material $(2 \mathrm{Cu})$ in result of human activities. Colluvial character of these soils was highlighted at the second level of classification by adding colluvic supplementary qualifier.

Profile 6 was located in Kozielec II Vineyard in the lower slope position, a few meters below Profile 7. This pedon had the smallest thickness of solum 
among all the investigated soils (Table 1). It is limited only to 25 centimetres - the lower boundary of the humus horizon and the depth of the former arable layer (Fig. 2). Parent material had obvious finely layered stratification of fluviatile or glaciofluvial origin. Location over floodplain suggests that the sediments are older than Holocene alluvium and may be associated with Pleistocene period. Those layered deposits have the features of silty rhythmite which may indicate that they are the remnants of the Late Glacial kame terraces. The complex system of this type of terraces within the Lower Vistula Valley at the altitude between 72-35 m a.s.l. was described by Kordowski [25]. Light colour of humus horizon, lack of diagnostic horizons and well visible layering allowed to classify the soil as Fluvisol [20]. Humus horizon had totally different texture in comparison with subsoil. It was former arable layer and had properties similar to the colluvium in Profile 4,5 and 7. The contemporary slope in this place has a straight shape and it is highly probable that humus horizon contains slope sediments. Nevertheless, the small thickness of the solum is typical for truncated soils. Profile 6 is probably located at the place where there originally was a small convexity. This form together with the primeval soil was destroyed during levelling works (some small human-made terraces are still visible on the slope) or by erosional processes.

The last soil profile (Kozielec III - Profile 8) represented Chernozem and was located on a small hill in the middle part of the Lower Vistula Valley slope. The humus horizon of this soil was partially ploughed at the depth of $18 \mathrm{~cm}$. It fulfilled all diagnostic criteria of chernic horizon: it had significant thickness, well-developed aggregate structure, more than $1 \%$ of the SOC, high base saturation and dark colour. Mineral material lying directly below A horizon contained large amounts of primarily and secondary carbonates (Table 1) and was classified as calcic horizon. The influence of slope processes on the development of Profile 8 is difficult to estimate. Topographic position and occurrence of colluvium in the immediate vicinity (toe positions) of the described hill allow to suppose that the soil has been partially truncated. On the other hand, a substantial thickness of A horizon, much higher than the former plough layer, suggests that pedon has not been strongly transformed by erosion.

\section{Stock of the organic matter}

The stocks of SOM in studied profiles ranged from 2,98 to $63,9 \mathrm{~kg} \mathrm{~m}^{-2}$. Taking these stocks into account, all pedons may be divided into two main groups (Fig. 3). The first group represents eroded soils with relatively low and average SOM stocks not exceeding $15 \mathrm{~kg} \mathrm{~m}^{-2}$ - Profiles 1, 2, 3, 6 and 8 . The second group includes colluvial soils extremely rich in humus - Profiles 4, 5 and 7.

The lowest values were recorded in Luvisols of Talerzyk Vineyard (Fig. 3). These soils had been eroded in the past, which suggests that the slope processes 


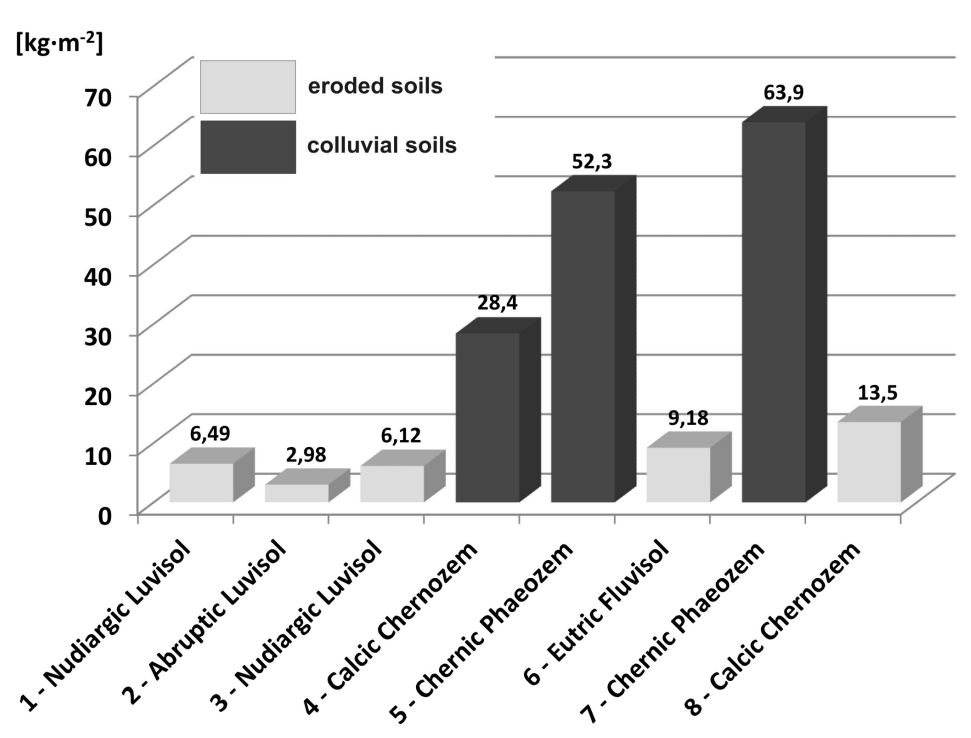

Fig. 3. SOM stocks.

could have a significant impact on reducing the amount of humus substances in surface horizons. However, similar SOM stocks $\left(3,29-6,35 \mathrm{~kg} \mathrm{~m}^{-2}\right)$ have been found in non-eroded forest Luvisols developed from glacial tills [30, 44]. Approximate values $\left(6,4-6,7 \mathrm{~kg} \mathrm{~m}^{-2}\right)$ were obtained by Schöning [48] for loess Luvisols covered by forests in France and Germany. Only slightly higher stocks up to a maximum of 9,6 $\mathrm{kg} \mathrm{m}^{-2}$ were confirmed in Luvisols of the Wielkopolska Region [28]. This indicates that although soils of Talerzyk were transformed by erosion, the SOM stocks in these pedons are comparable to the stocks in non-eroded Luvisols. Furthermore, strongly eroded pedons (1 and 3) with exhumed argic horizons (AB) had SOM stocks two times higher than slightly eroded Pedon 2 . The higher content of clay fraction in $\mathrm{AB}$ horizons, in comparison with horizon A in Profile 2, may enhance accumulation of humus substances.

Profile 6 was characterised by the smallest thickness of A horizon. Despite this, the SOM stocks in this pedon exceeded $9 \mathrm{~kg} \mathrm{~m}^{-2}$. This is due to the higher content of the SOC than in profiles 1-3. Humus horizon contained allochthonous material displaced along the slope. The primeval content of the SOM and thickness of humus horizon are very difficult to estimate. There is no data in the literature about natural soils developed from kame deposits in comparable environmental conditions. It may only be assumed that the former A horizon had properties similar to $2 \mathrm{Ab}$ horizon in Profile 7. This implies that the natural SOM stocks could be up to four times higher.

Among investigated eroded soils the stocks of SOM were the highest $\left(13,5 \mathrm{~kg} \mathrm{~m}^{-2}\right)$ in Profile 8 - Gleyic Calcic Chernozem. This soil developed under semi-hydrogenic conditions which led to slow decomposition of organic matter 
and accumulation of a significant amount of humus in the past [26, 27]. The primeval amount of humus in this pedon was probably higher than contemporary stocks. Previous studies conducted within the Chełmno Plateau demonstrated that the SOM stocks in similar Gleyic Chernozems ranged between 11,1-23,5 $\mathrm{kg} \mathrm{m}^{-2}$ [13]. According to this data, primeval SOM stocks in the described soil could be similar to the contemporary one or it could be even double reduced in result of agricultural use. At this stage of research it is difficult to estimate the influence of erosion on the SOM stocks.

Definitely higher stocks of soil organic matter, exceeding $28 \mathrm{~kg} \mathrm{~m}^{-2}$, in the second group of profiles (colluvial soils) resulted mainly from a significant thickness of humus horizons (Fig. 4). The SOC contents in the colluvial deposits were not an essential factor affecting the SOM stocks and ranged from 3,9 to $34,8 \mathrm{~g}$ $\mathrm{kg}^{-1}$. Furthermore, in some colluvial horizons the percentage contents of carbon were similar to A horizons of eroded soils. In view of location of colluvial soils in the lower parts of the slopes and greater influence of ground water, the higher contents of the SOC could be expected $[30,35]$. This is confirmed by considerably higher soil carbon content in the buried $2 \mathrm{Ab}$ horizon which was developed in natural environmental settings. Instead, comparable contemporary conditions conducive to the biological activity were characterised for both groups of soils - eroded and colluvial soils as evidenced by low values of the C:N ratio. The pace of humification and mineralization of organic matter could be aligned in investigated truncated soils and colluvial pedons. Hence, the accumulation of humus colluvial material was probably the main factor responsible for exceptionally high SOM stocks. The primeval thicknesses of A horizons in colluvial soils were presumably comparable to the thickness of $2 \mathrm{Ab}$ horizon in Profile 7. By comparing the SOM stocks in this buried horizon with stocks in Profiles 5 and 7 it may be concluded that accumulation of slope deposits led to a doubling or even tripling of current stocks of organic matter in investigated colluvial soils.

An influence of vineyards on the SOM stocks was impossible to determine due to the short period of their operation. Grass vegetation between rows of
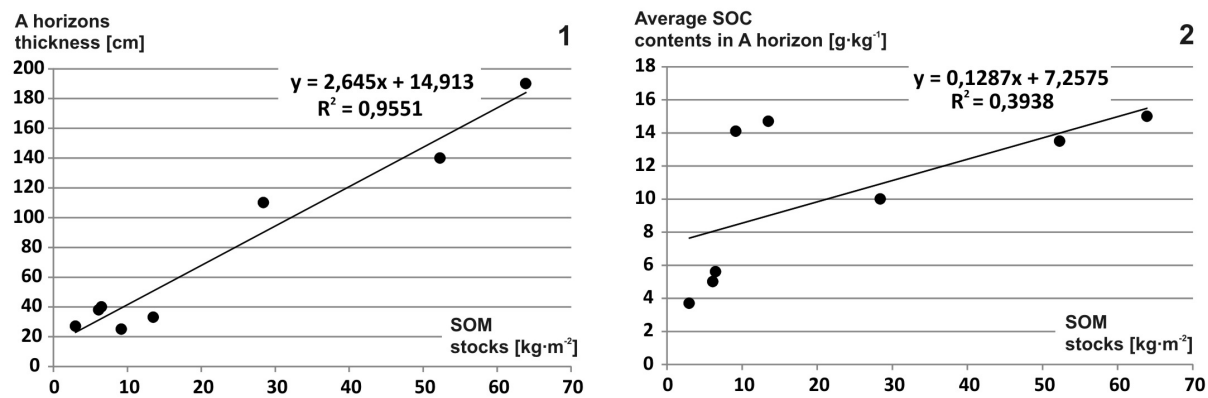

Fig. 4. Relationship between SOM stocks and: 1 - sum of A horizons thickness, 2 - average SOC contents in A horizons. 
grapevines reduced the rate of erosion. It should also enhance the SOM stocks in surface horizons in future [47].

\section{CONCLUSIONS}

Major findings in this study have lead to the following conclusions:

1. The soils of the studied vineyards were characterised by a high diversity of the SOM stocks. It was conditioned largely by the primeval heterogeneity of soil cover. The upper parts of the slopes were dominated by pedons with natural low amount of soil organic matter - Luvisols developed from glacial tills. Virgin soils located in toe and foot slope positions were under higher influence of ground water and contained much larger amounts of humus substances. They represented Chernozems and Phaeozems developed from layered fluvial sediments.

2. Conversion of natural vegetation into arable fields triggered slope processes and led to significant alteration of soils in the past. The translocation of soil material heightened differentiation in the stocks of organic matter.

3. All of the investigated Luvisols were truncated in result of accelerated erosion. However, there was not significant decline in organic matter in comparison with fully developed forest Luvisols.

4. Most Chernozems and Phaeozems located in toe and foot slope positions were enhanced in the SOM stocks (at least a twofold increase) due to accumulation of humus colluvial material on their surface.

5. Introduction of viticulture reduced the soil erosion, which is connected with plantation of dense grass vegetation between rows of vine. The short period of existence of vineyards makes it impossible to determine the impact of grass roots decay on carbon content in surface soil horizons. To determine this effect, long-term monitoring research is necessary.

\section{REFERENCES}

[1] B artkowiak A., Długos z J.: J. Elementol., 15(3), 445, 2010.

[2] B ednarek R., Dziadowiec H., Pokojska U., Prusinkiewicz Z.: Badania ekologiczno-gleboznawcze. PWN, Warszawa, 344, 2004.

[3] B e d n a r e k R., S z r e j d e r B.: Soil cover structure of the representative catchment of Struga Toruńska river. [In]: K e j n a , M., U s c k a , J. (Eds.), Integrated Monitoring of the Natural Environment Functioning and Monitoring of Geoecosystems in the Growing Human Activity Conditions. State Inspectorate for Environmental Protection, NCU, Torun, 243, 2004.

[4] C a 1 d e ró n F.J., J a c k s o n L.E., S c o w K.M., R o 1 s t o n D.E.: Soil Biol. Biochem., 32, $1547,2000$.

[5] C a 1 d e rón F.J., J a c k s o n L.E., S c o w K.M., R o 1 s t o n D.E.: Soil Biol. Biochem., 65, $118,2001$.

[6] C a m b a r d e 11 a C.A., E 11 i o t t E.T.: Soil Sci. Soc. Am. J., 56, 777, 1992. 
[7] Classification of Polish Soils. Soil Sci. Annual, 62(3), 193, 2011.

[8] Daniels R.B.: Soil erosion and degradation in the southern Piedmont. [In]: Wolman, M.G., F o u r n i e r, E. (Eds.), Land Transformation in Agriculture. Wiley, New York, USA: 407428, 1987.

[9] D ą b k o w s k a - N a skręt H., J a w o r s k a H.: Soil Sci. Annual, 48 (1/2), 59, 1997.

[10] D ą b k ow sk a - N a sk ręt H., J a w o r s k a H.: Soil Sci. Annual, 48 (3/4), 123, 1997.

[11] D otterweich M., Rodzik J., Zgłobicki W., Schmitt A., Schmidtchen G., B ork H.-R.: Catena, 95, 50, 2012.

[12] D o t t erwe i ch M., S t a nkoviansky M., Minár J., K o co Š., P a p čo P.: Geomorphology, 201, 227, 2013.

[13] D z i a d ow i e c H., P li c ht a W.: AUNC, Biologia, 35, 41, 1987.

[14] Eynard A., Schumacher T.E., Lindstrom M.J., Malo D.D.: Soil Tillage Research, 81, 253, 2005.

[15] FAO: Guidelines for Soil Description, Fourth edition. FAO, Rome, 2006.

[16] G a 1 o n R.: Pr. Geogr. IGiPZ PAN, 29, 129, 1961.

[17] G a lo n R.: Prz. Geogr., 40 (2), 307, 1968.

[18] G1 a d s t o n e s J.: Viticulture and Environment. Winetitles, Adelaide, 1992.

[19] G o n e t S.: Ochrona zasobów materii organicznej gleb. [In:] Gonet S., Markiewicz M., Rola materii organicznej w środowisku. Polskie Towarzystwo Substancji Humusowych, Wrocław, 7, 2007.

[20] IUSS Working Group - FAO: WRB-World Reference Base for Soil Resources 2014. World Soil Resources Report No. 106. FAO, Rome, 181, 2014.

[21] J a n k a u sk a s B., F u 11 e n M.A.: Canadian J. Soil Sci., 82, 311, 2002.

[22] J ó z e fa c i u k, C., J ó z e f a c i u k, A.: The erosion mechanisms and methodological indicators for the research on erosion. Environmental Monitoring Library, 1996.

[23] K 1 i m o wi c z Z., U ziak S.: Catena, 43, 177, 2001.

[24] K obiers ki M.: Morphology, Properties and Mineralogical Composition of Eroded Luvisols in Selected Morainic Areas of the Kujavian and Pomeranian Province. University of Technology and Life Sciences, Bydgoszcz, 2013.

[25] K o r d o w s k i J.: Landform Analysis, 25, 43, 2014.

[26] $€$ a b a z B., K a b a ła C.: Soil Science Annual, 65, 2, 80, 2014.

[27] Ł a b a z B., B og a c z A., K a b a ł a C.: Soil Science Annual, 65, 3, 103, 2014.

[28] M a r c in ek J., K o m is a r e k J.: Zesz. Probl. Post. Nauk Roln., 411, 113, 1993.

[29] M a r c in e k J., K o m i s a r e k J.: Anthropogenic Transformations of Soils of Poznań Lakeland as a Results of Intensive Agricultural Farming. AR, Poznań, 2004.

[30] Markiewicz M., Świto niak M., B ednarek R., Gonet S.S.: Zasoby materii organicznej. [In:] Ś wit on i a k M., J a nk ow sk i M., B e dn are k R., (Eds.): Antropogeniczne przekształcenia pokrywy glebowej Brodnickiego Parku Krajobrazowego. Wyd. Nauk. UMK, Toruń, 129, 2014.

[31] Mark s L.: Quat. Sci. Rev., 44, 81, 2012.

[32] Martine z-Cas a s ov as J.A., R a mos M.C.: Soil Use Manag., 25, 183, 2009.

[33] M e nd y k Ł., M a rki e wi c z M., Ś wit on iak M.: Catchments of disappearing lakes in glacial meltwater landscapes (Brodnica Lake District). [In:] Ś w i t o n i a k M., Charzyński P., (Eds.): Soil Sequences Atlas. Wyd. Nauk. UMK, Toruń, 93, 2014.

[34] M end y k Ł., Ś witon iak M., B ed narek R., F a l kow ski A.: Soil Science Annual, 66(1), 29, 2015.

[35] Mi ch als ki A.: Episteme,18/3, 329, 2013.

[36] Munsell Soil Colour Charts: Grand Rapids, MI, USA, 2009.

[37] O 1 s o n K.R., P hill i p s S.R., K i t u r B.K.: Soil Sci., 157(2), 108, 1994.

[38] Orzechowski M., S mólczyński S., Sowiński P.: Soil Sci. Annual, 55(2), 311, 2004.

[39] P a l u s z e k J.: Stud. Geogr., 45, 279, 2010. 
[40] P a 1 u s z e k J.: Soil Sci. Annual, 64 (2), 41, 2013.

[41] Part on W.J., S chi m e 1 D.S., C ol e C.V., Oj i m a D.S.: Soil Sci. Soc. Am. J., 51, 1173, 1987.

[42] Phillips J.D., S lattery M., Gares P.A.: Geomorphology, 28, 119, 1999.

[43] P o d l a s i ń s k i M.: Denudation of Anthropogenic Impact on the Diversity of Soil Cover and Its Spatial Structure in the Agricultural Landscape of Moraine. West Pomeranian University of Technology, Szczecin, 2013.

[44] P o k o j s k a U.: Adsorpcja i wymiana kationów w próchnicach leśnych. Rozprawy. UMK, Toruń, 1992.

[45] Pr ze w o źn a B.: Soil Sci. Plant Nutr., 60, 1, 30, 2014.

[46] Rodzik J., Mroczek P., Wiśniewski T.: Catena, 117, 50, 2014.

[47] Ruiz-Colmenero M., Bienes R. E1dridge D.J., Marques M.J.: Catena, 104, $153,2013$.

[48] S chön ing I.: Organic matter stocks in temperate forest soils: Composition, radiocarbon age and spatial variability. PhD Thesis. München, 110, 2005.

[49] S in k i e w i c z M.: The development of anthropogenic denudation in central part of northern Poland. UMK, Toruń, 1998.

[50] S i x J.K., E 11 i o t E.T., P a u s ti a n K.: Soil Sci. Soc. Am. J., 63, 1350, 1999.

[51] S m o ls k a E.: Landf. Anal., 3, 25, 2002.

[52] S m o $1 \mathrm{~s} \mathrm{k}$ a E.: Geochronometria, 38 (4), 325, 2011.

[53] S mól c zyń ski S., Or ze ch ow ski M.: J. Elem., 15 (1), 177, 2010.

[54] S m ó 1 c z y ń ski, S., K a l i s z, B., Or z e c how s k i, M.: Polish J. Environ. Stud., 20 (3), $755,2011$.

[55] S o m m e r M., Schlichting E.: Geoderma, 76, 1, 1997.

[56] Ś wit o n i a k.: Catena, 116, 173, 2014.

[57] Świtoniak M., Bednarek R.: Denudacja antropogeniczna. [In:] Antropogeniczne przekształcenia pokrywy glebowej Brodnickiego Parku Krajobrazowego. [eds.] Ś w i t o n i a k M., J a n k ow s ki M., B e d n a r e k R., Wyd. Nauk. UMK, Toruń, 57, 2014.

[58] Ś w i t o n i a k M., Mroczek P., Bednarek R.: Catena, (2014), http://dx.doi.org/10.1016/j.catena.2014.09.005 (in press).

[59] Tan Z.X., L a 1 R., S m e c k N.E., C a 1 h o u n F.G.: Geoderma, 121, 187, 2004.

[60] T is d a 11 J.M.: Formation of soil aggregates and accumulation of soil organic matter. [In:] Carter, M.R., Stewart, B.A. (Eds.), Structure and Organic Matter Storage in Agricultural Soils. Lewis Publishers, Boca Raton, 57, 1996.

[61] We c k w e r th P.: Przegl. Geogr., 78 (1), 47, 2006.

[62] We c kwe r th P.: Landform Analysis, 14, 57, 2010.

[63] W h i t e R.E.: Soils for Fine Wines. Oxford Univ. Press, New York, 2003.

[64] Van Re e uvijk L.P.: Procedures for Soil Analysis. $7^{\text {th }}$ Ed., Tech. Rep., 9, ISRIC-World Soil Information, Wageningen, Netherlands, 2006.

\section{WPEYW EROZJI ANTROPOGENICZNEJ NA ZASOBY GLEBOWEJ MATERII ORGANICZNEJ W WINNICACH KOTLINY FORDOŃSKIEJ}

Streszczenie. Celem badań było określenie wpływu erozji antropogenicznej na podstawowe właściwości i zasoby materii organicznej w glebach winnic położonych na zachodnich zboczach Doliny Dolnej Wisły. Badaniami objęto cztery winnice położone $30 \mathrm{~km}$ na północny-wschód od Bydgoszczy. W ramach prac terenowych wykonano 44 wiercenia, na podstawie których wybrano 8 miejsc, w których wykopano odkrywki glebowe. Stanowiska badawcze odznaczały się znacznym zróżnicowaniem pokrywy glebowej. Zasoby glebowej materii organicznej w poszczególnych 
pedonach mieściły się w szerokim przedziale między 2,98 a 63,9 $\mathrm{kg} \mathrm{m}^{-2}$. W górnych odcinkach zbocza Doliny Dolnej Wisły dominowały Luvisole rozwinięte z glin lodowcowych. W dolnej części zboczy występowały gleby z dobrze rozwiniętymi poziomami próchnicznymi zaklasyfikowane jako Phaeozemy i Chernozemy. Skałami macierzystymi tych gleb były warstwowane osady wodnego pochodzenia. Erozyjne przemieszczenie materiału glebowego doprowadziło do powiększenia naturalnego zróżnicowania zasobów glebowej materii organicznej. Pomimo iż, Luvisole odznaczały się znacznym zerodowaniem, nie odnotowano w nich znacznego spadku zasobów węgla organicznego w porównaniu z analogicznymi naturalnymi glebami leśnymi. Akumulacja próchnicznych deluwiów u podnóża zboczy doprowadziła jednak do znacznego wzrostu zasobów próchnicy w większości Phaeozemów i Chernozemów. Stosunkowo krótki okres funkcjonowania winnic uniemożliwia określenie wpływu roślinności trawiastej porastającej międzyrzędzia na zawartość węgla w poziomach powierzchniowych badanych gleb. 